\title{
EEN BEHARTIGINGSWAARDIG WOORD OVER GENEESKUNDIGE ARMENVERZORGING.
}

Ingezonden.

Bij de uitbreiding welke, vooral in onze dagen, het begrip "geneeskunde" zoo teregt heeft verkregen, kan en mag men het geneeskundig hulpbetoon bij armen niet langer tot enkel hulpbetoon in yeval van ziekte bepalen, maar moet men hieronder ook het voorkomen van ziekten begrijpen, en de pligt om zooveel mogelijk de regelen der gezondheidsleer toe te passen. Wie ook ter wereld zich van het verwezenelijken van zulk een begrip mag ontslagen rekenen, de diaconiën zeker niet, die hare oorspronkelijke instelling, haar beginsel, geheel zonden verloochenen, indien zij uitshitend op den tot nog toe gevolgden weg bleven voortgaan. Iiefdadigheid is haar doel, liefdadigheid was het beginsel hetwelk haar, eeuwen geleden, in het aanzijn riep, en met de liefdadigheid is het slecht overeen te brengen zóóveel oorzaken van ziekten, van verkorting van het menschelijk leven en van het vroegtijdig afsterven van duizende kinderen te laten voortbestaan, als er $\mathrm{nn}$ nog anwezig zijn. Bij verschillende gelegenheden is het reeds gezegd, en wij willen het daarom niet meer herhalen, dat die oorzaken gelegen zijn in de hizen waarin onze armen wonen; in het voedsel en den drank warmede zij zich moeten voeden en laven; in de lucht die ze inademen, in de straten, steden en grachten, waar hunne woningen gijn gelegen; in de opvoeding die zij genieten. Het behoort niet hier ter plaatse, een en ander met feiten te bewijzen, die feiten zijn reeds zoo herhaaldelijk vermeld, dat wij meenen te kunnen volstaan met te wijzen op de sterfte in de verschillende gedeelten der stad Amsterdam, die in sommige arme buurten dubbel zoo sterk is, als in de buurten waar meer gegoeden wonen (in de eerste 1 van elke 25 inwoners, in de lantsten 1 van elke 58 ì 54 . Zie Weekblad v. geneeskrund. 1852 $n^{0}$.37); - wij wijzen op de offers die de noodlottige jaren $1846 \mathrm{cn}$ 184i van de armen en de armbesturen hebben geëischt; - op de 
ondervinding van ieder geneeskundige die armen behandelt. Verbeteringen hier in te brengen is geene utopie: eene utopie is eene physieke onmogelijkheid, maar hier is alles mogelijk, alles doenlijk, voor geduld, volharding, en goeden wil.

Doch tot het ten uitvoer leggen en instellen dier verbetering, behoort men eerst goed te kenuen wat men verbeteren kan. Kennis dus van de behoefte is het allereerst noodzakelijke. Die kennis kan eerst door jaren lange ondervinding en verkeer onder de behoeftigen geboren worden. Het eerst van alles mag men haar derhalve bij de geneeskundigen der armen zoeken. Maar dan moeten die geneeskundigen ook bekend zijn met al de armen hunner wijk, en dan moet die wanorde ophouden, zoo als rij nu op vele plaatsen bestaat, dat in eene en dezelfde wijk somtijds rier tot vijf geneeskundigen, geheel zonder eenig verband onderling, armen behandelen. Dit heeft zelfs nu en dan in enkele huisgezinnen plaats. Hiervan is het gevolg, dat alle die wijk slechts bij gedeelten kennen. Het ware wenschelijk, dat overal de geneeskundige behandeling van alle armen in eene en dezelfde buurt uitsluitend aan é́n geneeskundige opgedragen wierd, onverschillig tot welke geloofsbelijdenis de arme behoort. Men zal toch niet kunneu beweren, dat de godsdienst. bijzondere ziekte-vormen schept, of wijziging in de ziekenbehandeling kan maken. Tot de uitvoering van dit denkbeeld zal echter voor het oogenblik niet overal de mogelijkheid bestaan. Maar waar van wege de diakoniën van verschillende gezindheden in de geneeskunlige armenverzorging wordt voorzien, daar zou het aantal geneeskundigen dat voor diaconiën werkzaam is, kunnen geroegd worden bij de van wege het Gemeentebestuur angestelden.

Men zou de stad naar dit getal in buurten kunnen verdeelen, en het opzigt over de geneeskundige behandeling in die buuten opdragen kunnen aan een collegie, zamengesteld uit buurtmeesters der stads-wijken en armbestuurders der onderscheidene diaconiën, naar nate het getal armen, dat in de buurt woont. Het benoemen van geneeskundigen, het geven van hun ontslag, de wijze van bedeeling, de contrôle over hunne geneesheeren en hunue armen, in een woord alles wat tegenwoordig tot de attributen van het stadshestrur en de diaconiën behoort, behoeft daaronder volstrekt niet het minste te lijden of verkort te worden. Men vereenigt zich slechts tot het geven van geneeskundige hulp. Het oprigten van bij-apotheken en van meer zittingsplaatsen roor de geneeskundigen zouden echter in sommige steden noodzakelijke veranderingen moeten zijn, waarbij de geneeskundige armendienst zeer veel winnen zal. De godsdienstige 
gebruiken kunnen en mogen hieronder niet lijden, vooreerst omdat een armbestuurder uit de gemeente, waarvan er armen in de wijk gevonden worden, zitting heeft in het wijk-collegie, en door hem de belangen zijner geadministreerden kunnen worden behartigd, en ten tweede kunnen de geneeskundigen hiervoor geen hinderpaal zijn, omdat er toch bezwaarlijk een geneeskundige zal gevonden worden, die zoo inhumaan zoude zijn, oin de armen aan zijne zorg toevertrouwd, in hunne godsdienstige gevoelen te krenken. De honoraria, die aan de medici gegeven worden, moeten naar een en clenzelfden grondslag geregeld worden, zij zullen, bij minder tijdsverlies, in waarde rijzen. Door deze zamenwerking verliest men niets, men wint er alleen en wel alles bij; - men verkrijgt een grooter personeel en dus minder zielen op ieder geneeskundige, daardoor kan men wegens minder tijd-verlies, op beter zorg aanspraak maken, en geeft men gelegenheid om de buurt in al hare onderdeelen goed te lepren kennen.

Zoodoende zullen en moeten de behoeften der armen uit een geneeskundig opzigt beter gekend worden en zulk eene kennis zal tot groote verbeteringen aanleiding geven. Is die kennis openbaar gemakkt, dan kan het niet anders of de verbeteringen znllen ook volgen. Niet dat wij van de stedelijke besturen of van de diaconiën zouden eischen, dat men bijv. huizen ging bouwen voor de armen, maar op grond van die kennis zoude men keuren kunnen invoeren, waarbij men ongezonde woningen afkeurde, men zoude de belasting van de bouwmaterialen kunnen kwijtschelden, men zoude de partikuliere ondernemingszucht op allerlei wijzen kunnen aanmoedigen; die niet zal achterblijven, voorzeker niet, wanneer men weet dat dergelijke ondernemingen goede geldbeleggingen zijn. $(*)$ Bovendien, de liefdadigheid heeft bij zoo vele gelegenheden getoond, dat zij voor geene opofferingen, boe groot ook, terug deinst, wanneer haar de behoeften der armen duidelijk waren gebleken. De roepstem van de gemeentebesturen en de diaconiën, zich in het openbaar maken der feiten uitende, waarbij de oorzaak der ziekte bij de armen duidelijk zoude werden aangegeren, zal zeker tot medewerking opwekken. Wanneer dan nog daarenboven op vele plaatsen ieder geneeskundige, die bij den tegenwoordigen stand van zaken armen behandelt, opregt en naar de inspraak zijns gewetens moet zeggen, dat ook de allergetrouwste pligtbetrachting zijnerzijds niets rermag om zoo veel

(*) Dat dit het geval is, is thans door verschillende voorbeelden, ook in ons vaderland, buiten twijfel gesteld.

RED. 
ellende te lenigen, maar dat die hnlp van elders moet komen, dan zal men toch bezwaarlijk eene liefdadigheid kunnen denken, die met voorkennis en met wetenschap het $\mathrm{kwaad}$ zou willen laten bestaan. Want wij schrijven het voortduren van de gebrekkige wijze waarop de armen aan hunne eerste levensbehoeften voldoen kumnen, niet toe aan onwil om dit te verbeteren, maar aan gemis van wetenschap met de behoeften, aan gebrek aan kennis ran zoo vele invloeden die het leven van duizenden ondermijnen. Heeft die kennis eenmaal die verbeteringen helpen tot stand brengen, dan kan het niet anders of het budget voor de geneeskundige dienst bij de armenbesturen zal en moet in den loop der tijden aanmerkelijk verminderen, epidemiën zullen niet meer zoo vele offers eischen, en de armen zelve zullen naar ligchaam en geest gezonder geworden zijn. En dat alléén, omdat men niet zal ternggedeinsd zijn voor de groote moeijelijkheden en opofferingen in 't begin, welke bezwaren spoedig wijken voor goeden wil, geduld en volharding. Dit zoude een liefdewerk zijn, zoo als er geen tweede is, en de geneeskunde zoude eene overwinnig vieren, zoo als geen andere wetenschap kan toonen!

Het bovenstaande, bijna woordelijk overgenomen uit een verslag omtrent de Geneeskundlige dienst bij de onderscheidene diaconiën te Amsterdam, voor eenigen tijd door Dr. A. H. Isna ËLs opgemaakt (*), is wel wardig in ruimeren kring te worden gelezen. In eenen tijd waarin op verschillende plaatsen, naar aanleiding der Gemeentewet, de bepalingen op de geneeskundige armenverzorging moeten worden berzien, meenden wij dat het nuttig kon zijn daarop de aandacht te vestigen. Het onderwerp is althans vrij wat meer aandacht wardig, dan op vele plaatsen daaraan wordt geschonken. $\mathrm{H}$.

(*) Geplaatst in hat Tijdschrift van de Nederl Maatsch. tot bevord. der Geneesk., IV Jrg. 1e Afd. blz. 84-122.

Vleeschzettin; te Pariss, 15 Julij per Ned. en Ned. Ct.

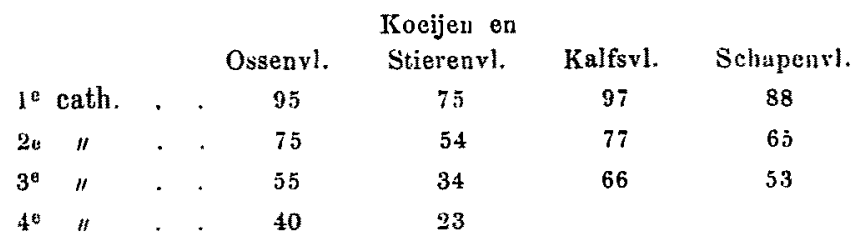

Zijnde een daling tegenover de vorigen zetting van $1^{0} \mathrm{Julij}$, van $6,1^{5}, 2^{5}$ en 5 Ct. per Ned. $\$$. 